\title{
ASPECTS OF PEDOGENESIS ON ROCKS OF THE CENTRAL PART OF THE BOHEMIAN CRETACEOUS BASIN
}

\author{
Anna ŽIGOVÁ*, Martin ŠŤASTNÝ and Jiří ADAMOVIČ
}

Institute of Geology of the Czech Academy of Sciences, Rozvojová 269, 16500 Praha 6-Lysolaje, Czech Republic

*Corresponding author's e-mail: zigova@gli.cas.cz

\begin{tabular}{l} 
ARTICLE INFO \\
\hline Article history: \\
Received 21 March 2019 \\
Accepted 28 August 2019 \\
Available online 10 October 2019 \\
\hline
\end{tabular}

Keywords:

Cretaceous sedimentary rocks

Clay minerals

Leptosols

Humification

Bwk horizon

\begin{abstract}
Pedogenesis was studied on clayey sandstones, calcareous sandstones, sandy marlstones and silty marlstones in the Bohemian Cretaceous Basin. These rocks were evaluated by petrography and $\mathrm{X}$-ray diffractometry. The soils were characterized on the basis of a variety of analyses of organic and anorganic components. Soil formation proceeded predominantly under neutral and basic conditions. Calcaric Leptosols are of smaller thickness and less prominent pedogenesis than Cambic Leptosols. The main pedogenetic process in all soils is humification. A rapid reduction of the amount of organic matter in soil profiles is typical for soils on clayey sandstone and sandy marlstone. The content of organic matter decreases gradually down the soil profiles on calcareous sandstone and silty marlstone. The intensity of modern pedogenesis is higher in Cambic Leptosols developed on calcareous sandstone and silty marlstone compared to Calcaric Leptosols on sandy marlstone and clayey sandstone. This is due to the more balanced quartz/calcite ratio in the parent material (1.06 for calcareous sandstone, 1.51 for silty marlstone). It appears that the most important factor in Leptosol development is the parent material and that the development towards Cambisols can be hardly expected on silicatecarbonate rocks with a high proportion of quartz.
\end{abstract}

\section{INTRODUCTION}

Pedogenesis on silicate-carbonate sedimentary rocks has a specific character. Soil development is controlled by the proportions of silicate and carbonate components in these rocks, with the quartz/calcite ratio being a key factor for the character of pedogenesis. Such soils mostly fall within the group of Leptosols.

Leptosols are very shallow, extremely gravelly/stony soils. They are developed over hard rocks of various lithologies at medium or high altitudes. Leptosols are distributed across all climatic zones, showing that the climatic factor is not a key one in their development. Leptosols may develop into Cambisols through transformation of soil material in situ and Bw horizon formation. The conditions under which such development may take place with respect to the parent materials of soils has been, however, poorly constrained by the literature.

Paleosols developed on silicate-carbonate sedimentary rocks are frequently used as an important proxy for paleoenvironmental reconstructions. These rocks are mostly of Cretaceous age - e.g., Mack (1992), Taylor (1996), McCarthy and Plint (2003), Varela et al. (2018) and do Nascimento et.al. (2019). Modern pedogenesis on silicate-carbonate sedimentary rocks has been described from different regions but concentrates exclusively on sandstones.
These papers include studies of pedogenesis on Upper Cretaceous sandstones in Nigeria by Ogunwale et.al. (1975), on Upper Cretaceous subarkosic sands with lenses of gray kaolinite clay in the USA by Daniels and Gamble (1978) and on Lower Cretaceous glauconitic rocks in England by Loveland and Findlay (1982). The only paper related to the Bohemian Cretaceous Basin is the study on pedogenesis of the soil catena on calcareous sandstones from the Jizera Formation by Tomášek and Žáčková (1972).

The aim of this study is to characterize pedogenesis around the Leptosol/Cambisol transition on silicate-carbonate sedimentary rocks on the example of modern soils within the limits of the Bohemian Cretaceous Basin, Czech Republic. A detailed multidisciplinary study of soil profiles in this area was designed to provide information about the pedoenviroment on various parent materials and characterize their effect on the formation of the $\mathrm{Bw}$ horizon.

\section{STUDIED SITES}

Aspects of pedogenesis were studied at four representative sites covering the various parent rock lithologies in the central part of the basin. Positions of the individual sites are shown in Figure 1 and given in Table 1. Lithostratigraphy of the basin fill was revised by Čech et al. (1980) who provided descriptions of 


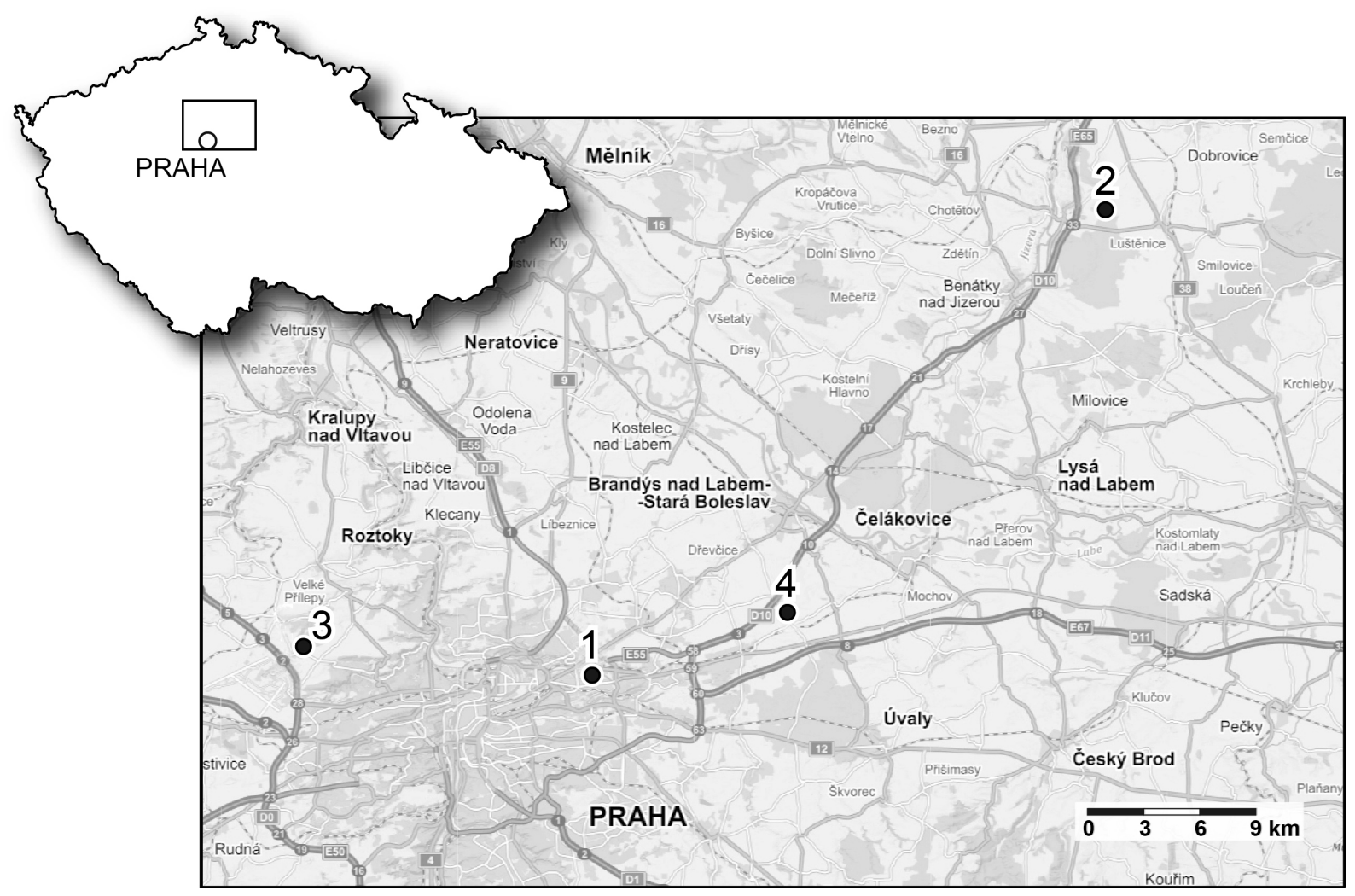

Fig. 1 Locations of the studied soil profiles.

1 - Klíčov, 2 - Brodce, 3 -Opukový lom, 4 -Zeleneč

type sections of the Peruc-Korycany Formation (Cenomanian), Bílá hora, Jizera and Teplice Formations (Turonian), Březno Formation (Coniacian) and Merboltice Formation (Santonian). Of these, the first three mentioned formations are preserved in the central part of the basin. Here, the Peruc-Korycany Formation is dominated by shallow marine clayey and quartzose sandstones 15-30 m thick, locally underlain by fluvial and estuarine sandstones to claystones several metres thick. The Bílá hora Formation consists of marine marlstones and sandy marlstones $30-50 \mathrm{~m}$ thick, and the Jizera Formation consists of silty-sandy marlstones to calcareous sandstones up to $120 \mathrm{~m}$ thick. More detailed characteristics of the mentioned formations were provided by Zelenka (1987), Hradecká (1994), Ziegler (1994) and Caracciolo et al. (2011). The latest geological map was compiled by Kovanda (1995).

The studied site of Klíčov (Fig. 2) lies in a municipal park in the northeastern part of Prague. It is characterized by clayey sandstones of the PerucKorycany Formation. Herbaceous vegetation with the presence of linden is typical for this area. The site of Brodce (Fig. 3) lies $42 \mathrm{~km}$ to the northeast of Prague. Parent material is represented by calcareous sandstones of the Jizera Formation. This area is agriculturally utilized, featuring arable soil with barley. The site of Opukový lom (Fig. 4) lies in the northwestern part of Prague in a former quarry. Parent material is represented by sandy marlstones of the
Table 1 Basic information on the studied soil profiles.

\begin{tabular}{lccc}
\hline Locality & Coordinate N & Coordinate E & Elevation \\
\hline Klíčov & $50^{\circ} 06^{\prime} 58^{\prime \prime}$ & $14^{\circ} 30^{\prime} 56^{\prime \prime}$ & $263 \mathrm{~m}$ a.s.l. \\
Brodce & $50^{\circ} 20^{\prime} 01^{\prime \prime}$ & $14^{\circ} 52^{\prime} 48^{\prime \prime}$ & $226 \mathrm{~m}$ a.s.1. \\
Opukový lom & $50^{\circ} 06^{\prime} 55^{\prime \prime}$ & $14^{\circ} 17^{\prime} 25^{\prime \prime}$ & $342 \mathrm{~m}$ a.s.l. \\
Zeleneč & $50^{\circ} 08^{\prime} 11^{\prime \prime}$ & $14^{\circ} 39^{\prime} 33^{\prime \prime}$ & $255 \mathrm{~m}$ a.s.1. \\
\hline
\end{tabular}

Bílá hora Formation. This site is covered by herbaceous vegetation with sparse pine, acacia and hazel. The Zeleneč site (Fig. 5) is situated $12 \mathrm{~km}$ to the east-northeast of Prague. The bedrock at this site is silty marlstone of the Bíla hora Formation. Former arable land was turned to a meadow with herbaceous vegetation and occasional walnut trees.

In the geomorphological subdivision (Balatka and Kalvoda, 2006), the sites of Klíčov and Opukový lom lie in the unit of the Pražská plošina Plateau. Klíčov lies in the district of the Pražská kotlina Basin and Opukový lom lies in the district of the Hostivická tabule Table. The Brodce site lies in the unit of the Jizerská tabule Table, in the district of the Košátecká tabule Table. The Zeleneč site lies in the unit of the Středolabská tabule Table, in the district of the Čakovická tabule Table.

Basic information about climate was provided by Quitt (1971). Climatic conditions of these areas correspond to the warm region W2 with long, warm and dry summers, a very short transition period with warm to moderately warm springs and autumns, and 


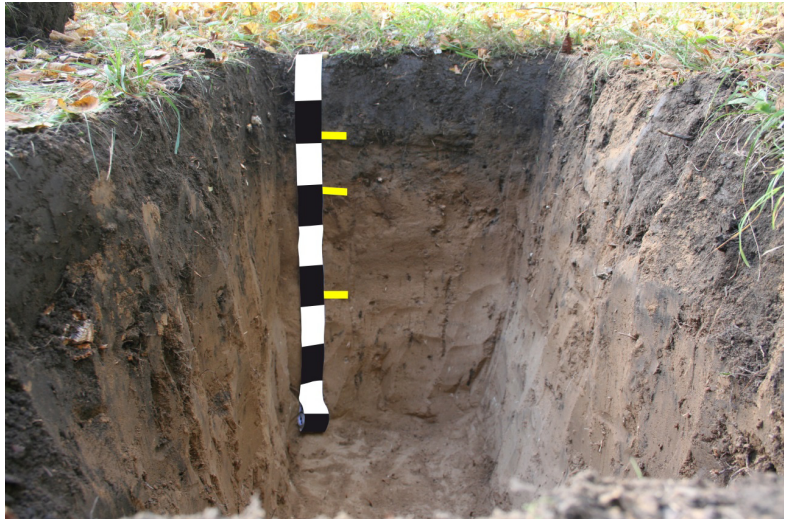

Fig. 2 Soil profile from the Klíčov site, each step on the scale bar equals $10 \mathrm{~cm}$ (photo by A. Žigová).

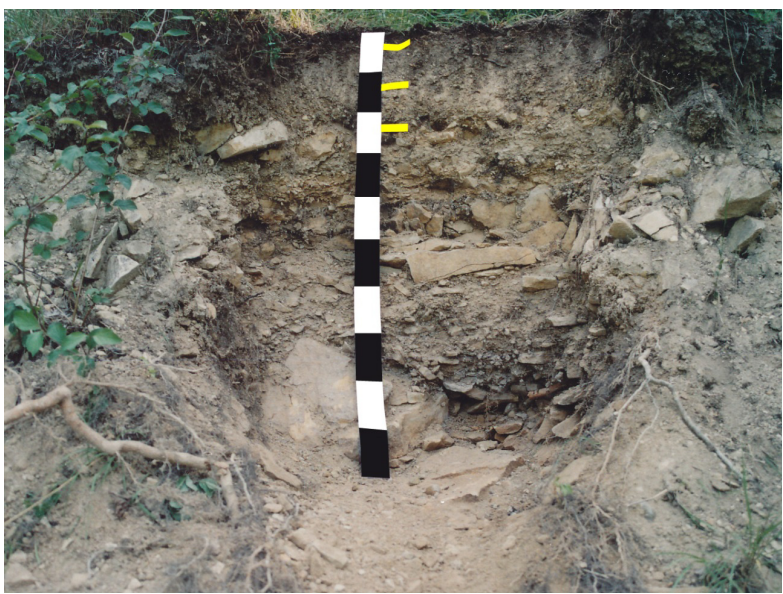

Fig. 4 Soil profile from the Opukový lom, each step on the scale bar equals $10 \mathrm{~cm}$ (photo by A. Žigová).

short, moderately warm, dry to very dry winters with very short duration of snow cower (160-170 days with mean temperature $\geq 10{ }^{\circ} \mathrm{C}, 90-100$ days with precipitations $\geq 1 \mathrm{~mm}$ and $40-50$ days with snow cover).

\section{MATERIAL AND METHODS}

Representative soil profiles were chosen based on a survey with a single-gouge auger. All soil profiles are located on flat, even portions of land surface. Characteristic soil profiles were excavated down to the parent material. Samples were collected from all horizons of soils. Soil morphology was determined according to Jahn et al. (2006). The color of individual soil horizons follows Munsell Soil Color Charts (2000).

Thin sections of rock were examined using the OLYMPUS BX51 polarizing microscope with the DP70 digital camera. Minerals present in powder samples of parent material and clay fraction of soils were identified by X-ray diffractometry. Prior to the $\mathrm{X}$-ray diffraction of soil samples, organic matter was removed using $30 \% \mathrm{H}_{2} \mathrm{O}_{2}$. Carbonates were eliminated by $0.1 \mathrm{~N}$ monochloracetic acid. Then, the

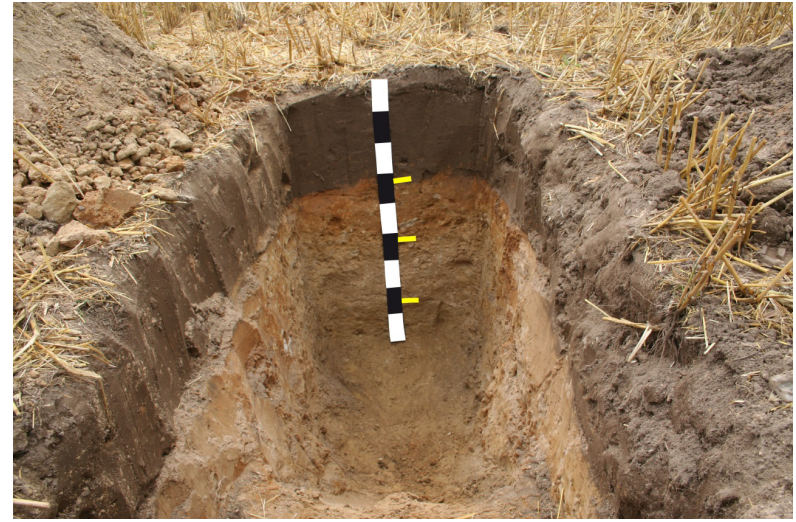

Fig. 3 Soil profile from the Brodce site, each step on the scale bar equals $10 \mathrm{~cm}$ (photo by A. Žigová).

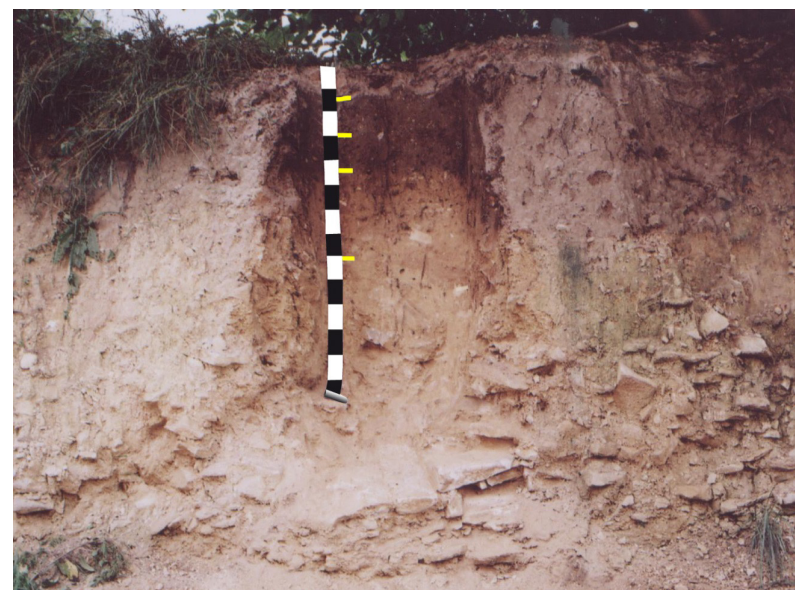

Fig. 5 Soil profile from the Zeleneč site, each step on the scale bar equals $10 \mathrm{~cm}$ (photo by A. Žigová).

samples were washed with distilled water. Clay fraction was obtained using a sedimentation method. Mineral composition was determined for soil fraction of clay, separated by sedimentation in distilled water, and mounted on oriented slides using the method of Jackson (1979). This fraction of soils was analyzed in natural state, then saturated for 4 hours in ethyleneglycol at $80{ }^{\circ} \mathrm{C}$ and heated at $550{ }^{\circ} \mathrm{C}$ for 4 hours. Individual spectra were obtained on the Philips PW 3710 diffractometer with Co radiation (Brodce and Opukový lom) and the Bruker D8 DISCOVER diffractometer with $\mathrm{Cu}$ radiation (Klíčov and Zeleneč). X-ray patterns were recorded at a goniometric shift of $1^{\circ} \cdot \mathrm{min}^{-1}, 2 \Theta$. The diffractograms were interpreted using Joint Committee on Powder Diffraction Standards (1986). Semiquantitative values were calculated based on the height of individual mineral basal peaks using correction coefficients (Žigová and Št'astný, 2014).

Analytical procedures for the determination of particle size distribution, chemical properties and organic matter of individual soils horizons followed standard methods (van Reeuwijk, 2002; Pansu and Gautheyrou, 2006). Particle size distribution was 


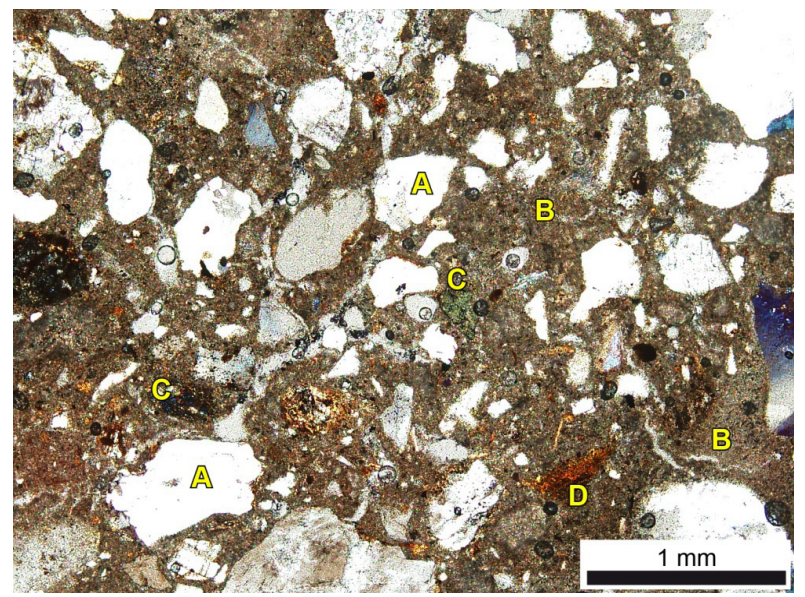

Fig. 6 A photomicrograph of a thin section of clayey sandstone from the Klíčov site, A - quartz, $\mathrm{B}$ - clay-carbonate matrix, C - glauconite, D - ironstone fragment (photo by A. Žigová, M. Št'astný).

determined using the pipette method. The $\mathrm{pH}$ values were measured in distilled water and $1 \mathrm{M} \mathrm{KCl}$ with a SenTix21 electrode using the soil: solution ratio of $1: 2.5$. The content of $\mathrm{CaCO}_{3}$ was measured by volumetric methods using $10 \% \mathrm{HCl}$. The formula $(\mathrm{S} / \mathrm{CEC}) \times 100$, where $\mathrm{S}$ denotes the sum of exchangeable bases $\left(\mathrm{mmol}^{+} / 100 \mathrm{~g}\right)$ and $\mathrm{CEC}$ is cation exchange capacity $\left(\mathrm{mmol}^{+} / 100 \mathrm{~g}\right)$, was used for the calculation of base saturation (in \%). Organic carbon was determined by wet combustion with a mixture of potassium dichromate and sulphuric acid, and total nitrogen using the Kjeldahl method.

\section{RESULTS AND DISCUSSION \\ PETROGRAPHY AND MINERALOGY OF ROCKS}

Parent material of the individual soil profiles was subjected to petrographic and mineralogical studies.

The rock from the Klíčov site is coarse-grained clayey sandstone with glauconite admixture. A thin section of the rock (Fig. 6) shows that the clasts are dominated by quartz grains $(65 \%$ of grains are $>500 \mu \mathrm{m}$ in size), mostly subangular or subrounded, and mostly with no contacts. Smaller grains are monocrystalline but larger grains are mostly polycrystalline, occasionally with a mosaic-like fabric (orthoquartzite). About 5-10\% of clasts are fragments of sericitized silty shale, and 2-3\% of clasts are ironstone fragments. Feldspar constitutes $10-15 \%$ of clasts. Mica (2-3\%) and glauconite (1\%, grains max. $200 \mu \mathrm{m}$ in size) are also present. No fossils are visible. Clay-carbonate matrix comprises $25-30 \%$ of rock volume. The following mineral composition of the rock was revealed by X-ray diffractometry: $53 \%$ quartz, $17 \%$ K-feldspar, $15 \%$ calcite, $11 \%$ plagioclase, $2 \%$ illite, $1 \%$ kaolinite and $1 \%$ amphibole.

The rock from the Brodce site is fine-grained calcareous sandstone with glauconite admixture, $85 \%$ of grains lie in the $63-250 \mu \mathrm{m}$ size interval. A thin section of the rock (Fig. 7) shows that the clasts are dominated by quartz grains, mostly angular or

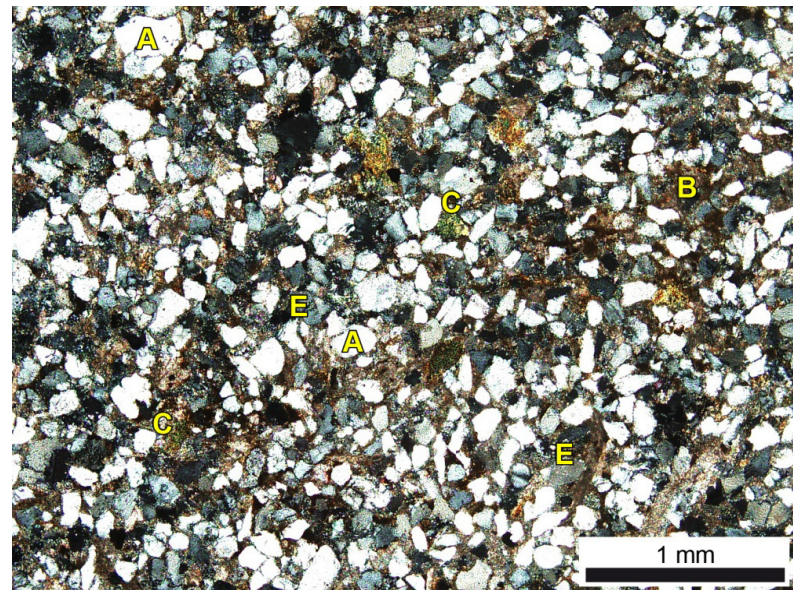

Fig. 7 A photomicrograph of a thin section of calcareous sandstone from the Brodce site, crossed polars, A - quartz, B - clay-carbonate matrix, C - glauconite, E - calcite (photo by A. Žigová, M. Št’astný).

subangular, and mostly with linear contacts. Most quartz grains are monocrystalline, with undulatory extinction. About $5 \%$ of clasts are bioclasts: sponge spicules, fragments of ostracod shells and skeletal fragments of bryozoans. Feldspar constitutes ca. $10 \%$ of clasts. Glauconite (1-2 \%, grains max. $200 \mu \mathrm{m}$ in size) and mica $(1 \%)$ are also present. Feldspar is accessory. Carbonate matrix comprises only ca. $10 \%$ of rock volume. The following mineral composition of the rock was revealed by X-ray diffractometry: $51 \%$ quartz, $48 \%$ calcite and $1 \% \mathrm{~K}$-feldspar.

The rock from the Opukový lom site is spiculitic sandy marlstone with glauconite admixture. A thin section of the rock (Fig. 8) shows that the clasts comprise $40 \%$ of the total rock volume, being dominated by quartz. $35 \%$ of clasts are in the siltsized fraction $(<63 \mu \mathrm{m})$ and $70 \%$ of clasts are in the fine sand fraction $(63-250 \mu \mathrm{m})$. All quartz clasts are angular or subangular, with no mutual contacts. About $5 \%$ of clasts are sponge spicules. Feldspar constitutes ca. $5 \%$ of clasts. Glauconite $(3-5 \%$, rounded grains max. $150 \mu \mathrm{m}$ in size) and mica (ca. $3 \%$, flakes max. $250 \mu \mathrm{m}$ in size) are also present. Most of the rock volume is formed by micritic carbonate with clay admixture. The following mineral composition of the rock was revealed by X-ray diffractometry: $60 \%$ quartz, $21 \%$ calcite, $8 \%$ kaolinite, $7 \%$ K-feldspar, $3 \%$ illite, and $1 \%$ gypsum.

The rock from the Zeleneč site is spiculitic silty marlstone with glauconite admixture. A thin section of the rock (Fig. 9) shows that the clasts comprise only $15-20 \%$ of the total rock volume, being dominated by silt-sized angular quartz and by sponge spicules, although other bioclasts are also abundant and locally pyritized, e.g., foraminiferal tests and fragments of ostracod shells. Glauconite grains, max. $100 \mu \mathrm{m}$ in size, are present in amounts of 5-10\% of the rock volume. Feldspar and mica are also present. The rock mass is formed by micritic carbonate with clay admixture, locally recrystallized into sparite. The overall texture of the rock shows that it could be a part 


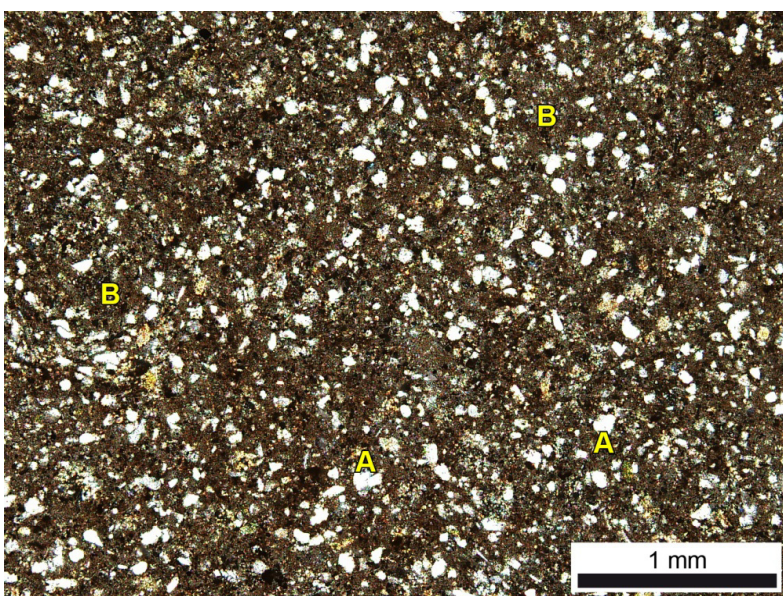

Fig. 8 A photomicrograph of a thin section of sandy marlstone from the Opukový lom site, crossed polars, A - quartz, B - clay-carbonate matrix (photo by A. Žigová, M. Št’astný).

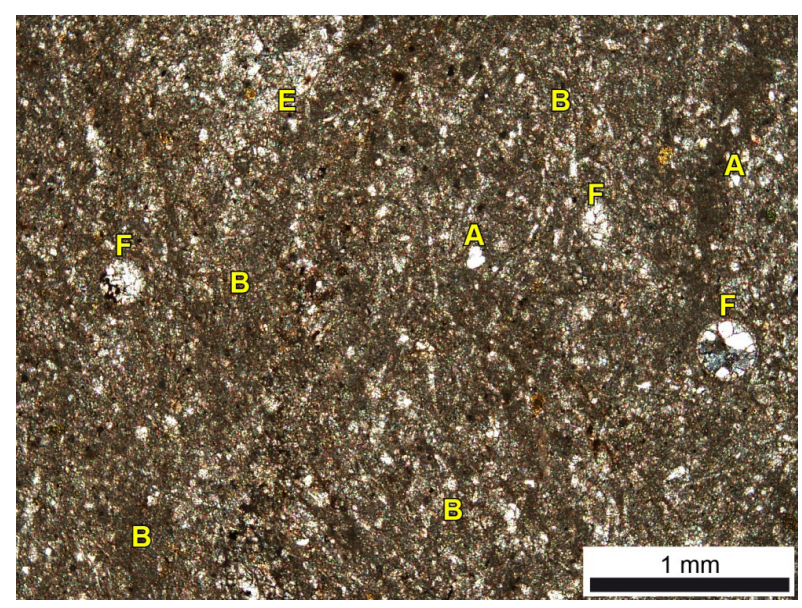

Fig. 9 A photomicrograph of a thin section of silty marlstone from the Zeleneč site, crossed polars, A - quartz, B - clay-carbonate matrix, E - calcite, F - fossil (photo by A. Žigová, M. Št'astný).

Table 2 Macromorphological properties of soils.

\begin{tabular}{|c|c|c|c|c|c|c|c|c|}
\hline Locality & Horizon & $\begin{array}{l}\text { Depth } \\
\text { (cm) }\end{array}$ & $\begin{array}{l}\text { Color } \\
\text { (moist) }\end{array}$ & Structure & $\begin{array}{c}\text { Rock } \\
\text { fragments } \\
\%\end{array}$ & Consistence & Roots & Boundary \\
\hline \multirow[t]{4}{*}{ Klíčov } & Ahk & $0-18$ & $10 \mathrm{YR} 2 / 2$ & GR & $2-5$ & FR & $\mathrm{F}$ & $\mathrm{CR}$ \\
\hline & AhkCk1 & $18-31$ & $10 \mathrm{YR} 3 / 3$ & SB & $5-10$ & FR & VF & $\mathrm{CR}$ \\
\hline & Ck1 & $31-67$ & $10 \mathrm{YR} 4 / 6$ & $\mathrm{~N}$ & $20-30$ & FR & VF & $\mathrm{CR}$ \\
\hline & $\mathrm{Ck} 2$ & $67-90$ & $10 \mathrm{YR} 5 / 3$ & $\mathrm{~N}$ & 40 & FR & VF & \\
\hline \multirow[t]{4}{*}{ Brodce } & Apk & $0-32$ & $10 \mathrm{YR} 3 / 3$ & SB & $2-5$ & VFR & $\mathrm{VF}$ & AT \\
\hline & Bwk & $32-52$ & 10YR 5/6 & $\mathrm{AB}$ & $20-30$ & FR & VF & $\mathrm{CR}$ \\
\hline & $\mathrm{Ck} 1$ & $52-75$ & $10 Y R$ 7/6 & $\mathrm{N}$ & $30-50$ & FR & $\mathrm{VF}$ & $\mathrm{CR}$ \\
\hline & $\mathrm{Ck} 2$ & $75-90$ & $10 Y R 7 / 4$ & $\mathrm{~N}$ & 60 & FR & VF & \\
\hline \multirow[t]{4}{*}{ Opukový lom } & Ok & $0+2$ & 10YR 2/1 & GR & 0 & FR & F & $\mathrm{CR}$ \\
\hline & Ahk & $0-11$ & $10 \mathrm{YR} 4 / 2$ & GR & $5-10$ & FR & $\mathrm{F}$ & CR \\
\hline & AhkCk & $11-20$ & $10 \mathrm{YR} 6 / 4$ & $\mathrm{~N}$ & $20-30$ & FR & $\mathrm{F}$ & $\mathrm{CR}$ \\
\hline & $\mathrm{Ck}$ & $20-70$ & $10 \mathrm{YR} 7 / 4$ & $\mathrm{~N}$ & 90 & FR & $\mathrm{F}$ & \\
\hline \multirow[t]{5}{*}{ Zeleneč } & Ahk1 & $0-15$ & $10 \mathrm{YR} 4 / 3$ & GR & $2-5$ & VFR & $\mathrm{F}$ & CR \\
\hline & Ahk2 & $15-30$ & $10 \mathrm{YR} 3 / 3$ & SB & $5-10$ & FR & $\mathrm{F}$ & $\mathrm{CR}$ \\
\hline & Ahk2Bwk & $30-43$ & $10 \mathrm{YR} 4 / 3$ & $\mathrm{AB}$ & $10-20$ & FR & $\mathrm{F}$ & $\mathrm{CR}$ \\
\hline & Bwk & $43-79 / 98$ & 10 YR $5 / 6$ & $\mathrm{AB}$ & $30-50$ & FR & $\mathrm{F}$ & $\mathrm{CR}$ \\
\hline & $\mathrm{Ck}$ & 79/98-198 & 10 YR $6 / 8$ & $\mathrm{~N}$ & 90 & FR & $\mathrm{F}$ & \\
\hline
\end{tabular}

GR - granular, AB - angular blocky, N - none, SB - subangular blocky, FR - friable, VFR - very friable, F - fine, VF - very fine, $\mathrm{C}$ - common, $\mathrm{CR}$ - clear, AT - abrupt

of an algal-bryozoan bioherm. The following mineral composition of the rock was revealed by X-ray diffractometry: $50 \%$ quartz, $33 \%$ calcite, $6 \%$ kaolinite, $5 \%$ rutile, $3 \%$ illite, $2 \% \mathrm{~K}$-feldspar and 1 $\%$ plagioclase.

The results show that all the studied rocks consist of quartz and clay-carbonate matrix as the main constituents. Individual rocks differ in their mutual proportions, texture and also in accessory minerals. The rocks at Opukový lom and Zeleneč differ notably from those at Klíčov and Brodce in their low contents of terrigenous material and the dominance of calcitic micrite with a variable proportion of clay. Terrigenous material is dominated by quartz at all sites, although feldspar is also present. Glauconite is a common admixture in all rocks, with the highest amounts encountered at Zeleneč.

\section{SOIL MORPHOLOGY}

Principal characteristics and soil horizon designation of individual profiles are presented in Table 2. Evaluation of these properties serves as a basis for soil classification.

Morphological analysis and configuration of diagnostic horizons of individual soil profiles show some differences. Individual soil profiles were 
Table 3 Particle size distribution of soils.

\begin{tabular}{lccccc}
\hline Locality & $\begin{array}{c}\text { Depth } \\
\text { cm }\end{array}$ & $\begin{array}{c}\text { Clay } \\
\mathbf{\%}\end{array}$ & $\begin{array}{c}\text { Silt } \\
\mathbf{\%}\end{array}$ & $\begin{array}{c}\text { Sand } \\
\mathbf{\%}\end{array}$ & Texture class \\
\hline Klíčov & $0-18$ & 14.2 & 37.1 & 48.7 & loam \\
& $18-31$ & 14.3 & 39.8 & 45.9 & loam \\
& $31-67$ & 12.4 & 35.2 & 52.4 & sandy loam \\
& $67-90$ & 12.9 & 27.5 & 59.6 & sandy loam \\
\hline Brodce & $0-32$ & 6.3 & 8.0 & 85.7 & loamy sand \\
& $32-52$ & 21.2 & 8.4 & 70.4 & sandy clay loam \\
& $52-75$ & 17.4 & 15.1 & 67.5 & sandy loam \\
& $75-90$ & 11.9 & 11.5 & 76.6 & sandy loam \\
\hline Opukový lom & $0+2$ & 20.6 & 62.4 & 17.0 & silt loam \\
& $0-11$ & 16.0 & 41.7 & 42,3 & loam \\
& $11-20$ & 21.9 & 36.5 & 41.6 & loam \\
\hline Zeleneč & $20-70$ & 19.8 & 45.9 & 34.3 & sandy loam \\
& $0-15$ & 10.1 & 17.0 & 72.9 & silt loam \\
& $15-30$ & 24.5 & 51.4 & 24.1 & silt loam \\
& $30-43$ & 25.3 & 56.1 & 18.6 & silt loam \\
& $43-79 / 98$ & 26.3 & 47.0 & 26.7 & silty clay \\
\hline
\end{tabular}

Clay $<0.002 \mathrm{~mm}$, silt $0.002-0.05 \mathrm{~mm}$, sand $0.05-2.00 \mathrm{~mm}$

classified according to the World Reference Base for Soil Resources (IUSS Working Group WRB, 2015). The soils developed on clayey sandstone (Klíčov) and sandy marlstone (Opukový lom) were classified as Calcaric Leptosols. The soils profiles developed on calcareous sandstone (Brodce) and silty marlstone (Zeleneč) were classified as Cambic Leptosols.

The Ok horizon in a thickness of $2 \mathrm{~cm}$ was identified only at the Opukový lom site which is covered by forest and by herbaceous vegetation. Soil profiles at the Klíčov and Opukový lom sites show various thicknesses of the Ahk horizons. The structure of these horizons is granular. The Ck1 horizon started at $31 \mathrm{~cm}$ in the Klíčov profile and at $20 \mathrm{~cm}$ in the Opukový lom area. The distribution of rock fragments across profiles is specific for each site but their contents generally increase down the profiles. The consistence of all horizons at Klíčov and Opukový lom is friable. The distribution and diameter of roots in the soil profiles correspond to the type of land use.

Properties of the Apk horizon at Brodce site are influenced by tillage activity. This horizon has a subangular blocky structure. The Zeleneč site is situated on former arable land now turned to a meadow. The total thickness of the Ahk1 and Ahk2 horizons is $30 \mathrm{~cm}$, which usually corresponds to ploughing activity. The differences in macromorphological characteristics of the Ahk1 and Ahk2 horizons, such as color, structure and content of rock fragments, and consistence is probably a result of the change in land use. The Brodce and Zeleneč profiles display the Bwk horizon with angular blocky structure, yellowish brown (10YR 5/6) in color and of different thickness. The $\mathrm{Ck} 1$ horizon started at $52 \mathrm{~cm}$ in the Brodce profile and at $79-98 \mathrm{~cm}$ in the profile at the Zeleneč site. The profiles differ in the contents of rock fragments in their bottom parts and in their thickness, which is probably due to different types of parent material. The distribution and diameter of roots in the soil profiles correspond to the type of land use.

\section{PARTICLE SIZE DISTRIBUTION IN SOILS}

Data on particle size distribution are presented in Table 3. Texture classes were evaluated according to Soil Survey Staff (2014). Soil profiles show different distributions of individual particle sizes. Sand fraction with relatively high content of clay is typical for the Klíčov site with clayey sandstone. Sand fraction dominates at the Brodce site with calcareous sandstone. Silt and sand fractions prevail in the whole profile except for the Ok horizon at the Opukový lom site with sandy marlstones. A prevalence of silt fraction and an increasing content of clay fraction, except for the Ahk1 horizon, were observed at the Zeleneč site with silty marlstone.

Classification to the texture classes follows from the proportions of clay, silt and sand fractions, which probably result from the type of rock. This fact is also supported by the distribution of clay-carbonate matrix and mineral grains in individual parent rocks, as shown by petrography study.

\section{CHEMICAL CHARACTERISTICS AND ORGANIC MATTER IN SOILS}

Chemical characteristics and data on organic matter are summarized in Table 4. The measured values were evaluated according to Baize (1993). The Klíčov site displayed a basic reaction and a neutral one in the Ahk horizon. Soil profile from the Brodce site revealed weakly acid reaction in the Apk horizon and a basic one in the lower part of the profile. The Opukový lom site shows a neutral $\mathrm{pH}$ in the upper part of the profile and a basic reaction in the $\mathrm{Ck}$ horizon. At the site of Zeleneč, the soil profile shows a basic reaction. 
Table 4 Chemical properties and organic matter characteristics of soils.

\begin{tabular}{|c|c|c|c|c|c|c|c|c|c|}
\hline Locality & $\begin{array}{c}\text { Depth } \\
\text { cm }\end{array}$ & $\mathrm{pH}_{\mathrm{H} 2 \mathrm{O}}$ & $\mathrm{pH}_{\mathrm{KCl}}$ & $\begin{array}{c}\mathrm{CaCO}_{3} \\
\% \\
\end{array}$ & $\begin{array}{l}\mathrm{BS} \\
\%\end{array}$ & $\begin{array}{c}\mathrm{CEC} \\
\mathrm{mmol}^{+} / \mathbf{1 0 0 g}\end{array}$ & $\begin{array}{c}C_{0 x} \\
\%\end{array}$ & $\begin{array}{l}N_{t} \\
\%\end{array}$ & $\mathrm{C} / \mathbf{N}$ \\
\hline \multirow[t]{4}{*}{ Klíčov } & $0-18$ & 7.33 & 7.14 & 2.0 & 100 & 20.24 & 1.98 & 0.17 & 11.65 \\
\hline & $18-31$ & 7.77 & 7.39 & 4.5 & 100 & 12.57 & 0.48 & 0.07 & 6.86 \\
\hline & $31-67$ & 8.13 & 7.59 & 4.2 & 100 & 10.88 & 0.16 & 0.03 & 5.33 \\
\hline & $67-90$ & 8.15 & 7.62 & 3.4 & 100 & 8.64 & 0.04 & 0.03 & 1.33 \\
\hline \multirow[t]{4}{*}{ Brodce } & $0-32$ & 6.19 & 5.97 & 0.1 & 73 & 7.28 & 0.62 & 0.09 & 6.89 \\
\hline & $32-52$ & 7.56 & 7.04 & 0.2 & 96 & 11.26 & 0.23 & 0.05 & 4.60 \\
\hline & $52-75$ & 8.22 & 7.80 & 19.0 & 100 & 8.04 & 0.33 & 0.05 & 6.60 \\
\hline & $75-90$ & 8.41 & 7.89 & 10.0 & 100 & 5.00 & 0.10 & 0.05 & 2.00 \\
\hline \multirow[t]{4}{*}{ Opukový lom } & $0+20$ & 7.31 & 6.78 & 2.8 & 94 & 92.05 & 20.32 & 0.54 & 37.63 \\
\hline & $0-11$ & 7.13 & 6.89 & 12.0 & 100 & 18.20 & 3.15 & 0.26 & 12.11 \\
\hline & $11-20$ & 7.33 & 7.15 & 16.0 & 100 & 10.05 & 1.46 & 0.10 & 14.60 \\
\hline & $20-70$ & 7.69 & 7.44 & 8.0 & 100 & 12.46 & 1.26 & 0.12 & 10.50 \\
\hline \multirow[t]{5}{*}{ Zeleneč } & $0-15$ & 8.46 & 7.95 & 10.0 & 100 & 7.79 & 0,93 & 0.11 & 8.45 \\
\hline & $15-30$ & 8.00 & 7.53 & 8.8 & 100 & 16.31 & 1.34 & 0.15 & 8.93 \\
\hline & $30-43$ & 7.96 & 7.45 & 8.0 & 100 & 16.44 & 1.09 & 0.13 & 8.38 \\
\hline & $43-79 / 98$ & 8.04 & 7.52 & 19.0 & 100 & 13.09 & 0.39 & 0.08 & 4.88 \\
\hline & 79/98-198 & 8.07 & 7.58 & 16.0 & 100 & 9.42 & 0.12 & 0.04 & 3.00 \\
\hline
\end{tabular}

$\mathrm{BS}$ - base saturation, $\mathrm{CEC}$ - cation exchange capacity, $\mathrm{C}_{\mathrm{ox}}$ - organic carbon, $\mathrm{N}_{\mathrm{t}}-$ total nitrogen

Table 5 Mineralogy of the clay fraction of soils.

\begin{tabular}{lccccccccccc}
\hline Locality & $\begin{array}{c}\text { Depth } \\
\mathbf{~ m ~}\end{array}$ & $\begin{array}{c}\mathbf{C h} \\
\mathbf{\%}\end{array}$ & $\begin{array}{c}\mathbf{I} \\
\mathbf{\%}\end{array}$ & $\begin{array}{c}\mathbf{K} \\
\mathbf{\%}\end{array}$ & $\begin{array}{c}\mathbf{S m} \\
\mathbf{\%}\end{array}$ & $\begin{array}{c}\mathbf{Q} \\
\mathbf{\%}\end{array}$ & $\begin{array}{c}\mathbf{K f} \\
\mathbf{\%}\end{array}$ & $\begin{array}{c}\mathbf{P I} \\
\mathbf{\%}\end{array}$ & $\begin{array}{c}\text { Am } \\
\mathbf{\%}\end{array}$ & $\begin{array}{c}\mathbf{G y} \\
\mathbf{\%}\end{array}$ & $\begin{array}{c}\mathbf{G e} \\
\mathbf{\%}\end{array}$ \\
\hline Klíčov & $0-18$ & 6 & 26 & 22 & 0 & 34 & 5 & 6 & 1 & 0 & 0 \\
& $18-31$ & 6 & 21 & 24 & 3 & 34 & 5 & 7 & 0 & 0 & 0 \\
& $31-67$ & 8 & 26 & 23 & 3 & 24 & 6 & 6 & 0 & 4 & 0 \\
& $67-90$ & 7 & 23 & 22 & 5 & 30 & 6 & 5 & 2 & 0 & 0 \\
\hline Brodce & $0-32$ & 2 & 7 & 14 & 0 & 65 & 5 & 5 & 2 & 0 & 0 \\
& $32-52$ & 0 & 8 & 33 & 5 & 49 & 5 & 0 & 0 & 0 & 0 \\
& $52-75$ & 4 & 8 & 48 & 2 & 34 & 3 & 0 & 0 & 0 & 1 \\
& $75-90$ & 2 & 7 & 35 & 1 & 51 & 3 & 0 & 1 & 0 & 0 \\
\hline Opukovýy lom & $0+2$ & 0 & 9 & 29 & 0 & 59 & 3 & 0 & 0 & 0 & 0 \\
& $0-11$ & 0 & 3 & 28 & 4 & 65 & 0 & 0 & 0 & 0 & 0 \\
& $11-20$ & 0 & 4 & 19 & 0 & 73 & 0 & 0 & 0 & 4 & 0 \\
& $20-70$ & 0 & 3 & 9 & 3 & 82 & 0 & 0 & 0 & 3 & 0 \\
\hline Zeleneč & $0-15$ & 0 & 21 & 41 & 0 & 38 & 0 & 0 & 0 & 0 & 0 \\
& $15-30$ & 0 & 15 & 37 & 0 & 44 & 4 & 0 & 0 & 0 & 0 \\
& $30-43$ & 0 & 19 & 41 & 0 & 35 & 5 & 0 & 0 & 0 & 0 \\
& $43-79 / 98$ & 1 & 20 & 36 & 1 & 38 & 3 & 1 & 0 & 0 & 0 \\
& $79 / 98-198$ & 0 & 6 & 33 & 0 & 61 & 0 & 0 & 0 & 0 & 0 \\
\hline
\end{tabular}

$\mathrm{Ch}$ - chlorite, I - illite, $\mathrm{K}$ - kaolinite, Sm - smectite, Q - quartz, Kf - K-feldspar, Pl - plagioclase, Am - amphibole, Gy gypsum, Ge - goethite

Carbonate contents in soil profiles from the individual sites are different. The lowest carbonate contents were documented in the soil profile at Klíčov and also in the Apk and Bwk horizons of the Brodce profile. Such distribution is probably associated with different petrographic composition of parent material at the studied sites.

Base saturation was reaching the value of $100 \%$ with the exception of the upper part of the soil profile at Brodce and the Ok horizon at the Opukový lom site. The observed trends in values of cation exchange capacity in the upper part of the individual soil profiles are different. Very high cation exchange capacity was found in the Ok horizon (Opukový lom). These values are the lowest in the Apk (Brodce) and Ahk1 (Zeleneč) horizons. Such distribution is probably related with the elevated content of sand fraction.

The results indicate that chemical properties of the studied profiles are influenced by the distribution of carbonate and clay content in soil matrix and parent material. 


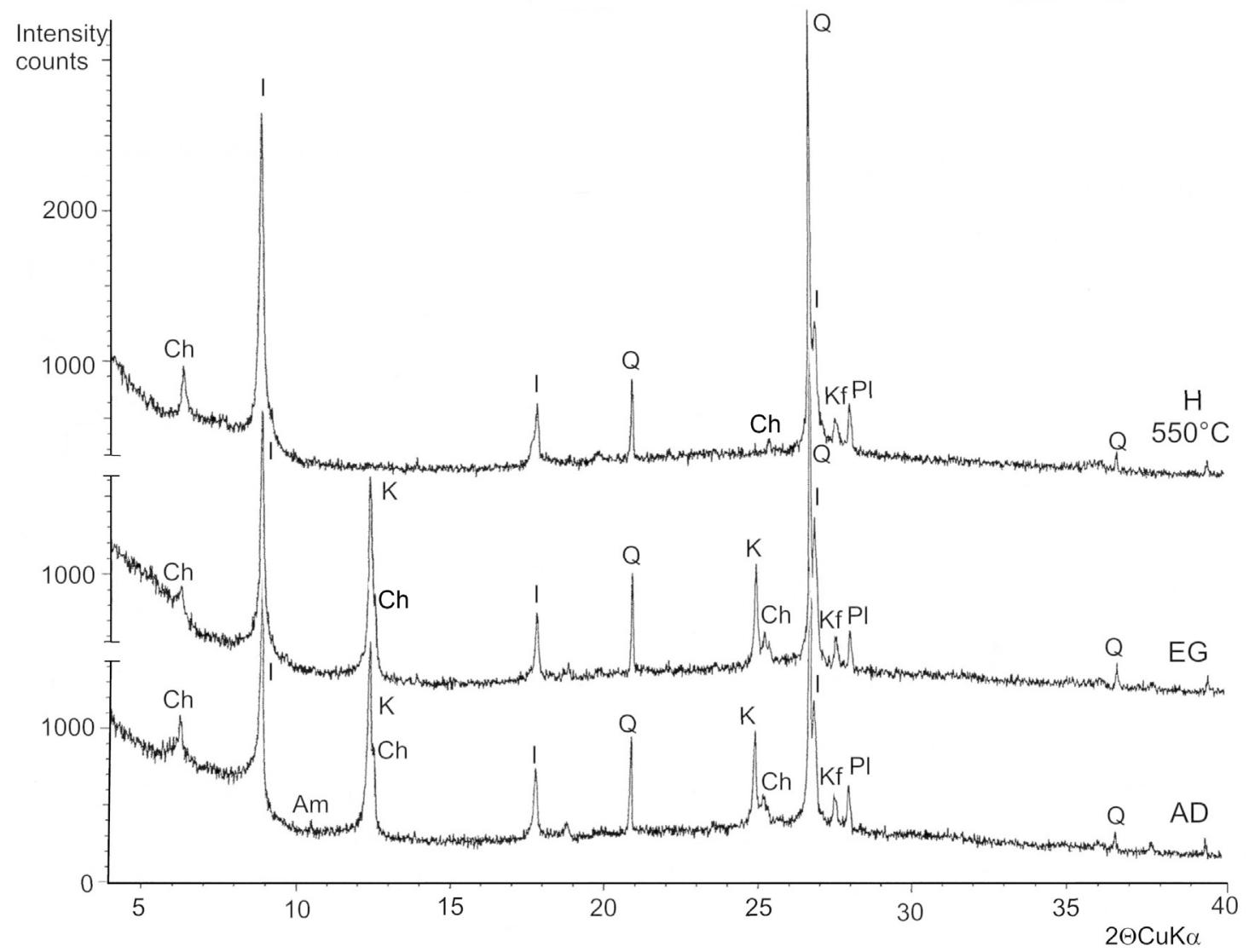

Table 10 X-ray diffractogram of clay fraction from the Ahk horizon at Klíčov, AD - air-dried, EG - ethylene glycol-solvated, $\mathrm{H}$ - after heating, Ch - chlorite, I - illite, $\mathrm{K}$ - kaolinite, Q - quartz, Kf - K-feldspar, $\mathrm{Pl}$ - plagioclase, Am - amphibole.

The values of organic carbon and total nitrogen are the highest in the Ok, Ahk and Apk horizons. The highest ones were found at the Opukový lom site. The lowest values of organic carbon and total nitrogen were documented at the Brodce site with calcareous sandstone. The $\mathrm{C} / \mathrm{N}$ value showed different degrees of enrichment of soil organic matter in nitrogen. A rapid decrease in organic matter was recorded in soils at the Klíčov and Opukový lom sites. The contents of organic matter gradually decrease down the profiles at the Brodce and Zeleneč sites. The results also show that the contents of soil organic matter were probably connected with the source of biomass and the type of land use.

\section{MINERALOGY OF CLAY FRACTION OF SOILS}

Mineral composition of the clay fraction of soils is summarized in Table 5. X-ray diffractograms are presented in Figure 10 (Klíčov, Ahk horizon), Figure 11 (Brodce, Apk horizon), Figure 12 (Brodce, Bwk horizon), Figure 13 (Opukový lom. Ahk horizon) and Figure 14 (Zeleneč, Ahk2 horizon), Figure 15 (Zeleneč, Bwk horizon). Calcite was not detected in the clay fraction of soils because it was removed in the process of sample preparation.

The most characteristics minerals of the clay fraction of soils developed on Cretaceous sediments of Cenomanian and Turonian age are quartz, kaolinite and illite. Quartz was identified based on diffraction lines of 4.25 and $3.34 \AA$. Kaolinite is characterized by diffraction line of 7.15 and occasionally also by $3.57 \AA$. Illite is characterized by diffraction lines of 10 and $4.43 \AA$. Chlorite shows basal reflections $14 \AA$ (unchanged after ethylene glycol solvation and heating) and $7.05 \AA$, which are of low intensities after previous sample treatment. Smectite was identified by the diffraction line of $17 \AA$ after ethylene glycol solvation. The other identified minerals include K-feldspar (3.24 $\AA$ ), plagioclase (3.19 $\AA$ ), gypsum (9.63 $\AA)$, amphibole $(8.41 \AA)$ and goethite $(4.18 \AA)$.

The Klíčov profile on clayey sandstone is characterized by relatively stable contents of all mineral components in the clay fraction. The amount of quartz ranges from 24 to $34 \%$. Relatively high is the content of K-feldspar and plagioclase. A small portion of gypsum was detected in the $\mathrm{Ck} 1$ horizon. Amphibole is present in the Ahk and $\mathrm{Ck} 2$ horizons as an accessory mineral. The most common clay minerals are kaolinite (22-24\%) and illite (21-26\%). Chlorite is present in amounts of 6-8\%. Smectite occurs as accessory mineral but is absent from the Ahk horizon. This mineral is probably a product of glauconite alteration.

The Brodce profile on calcareous sandstone is characterized by decreasing amounts of quartz towards the $\mathrm{Ck}$ horizon. K-feldspar is present in the 


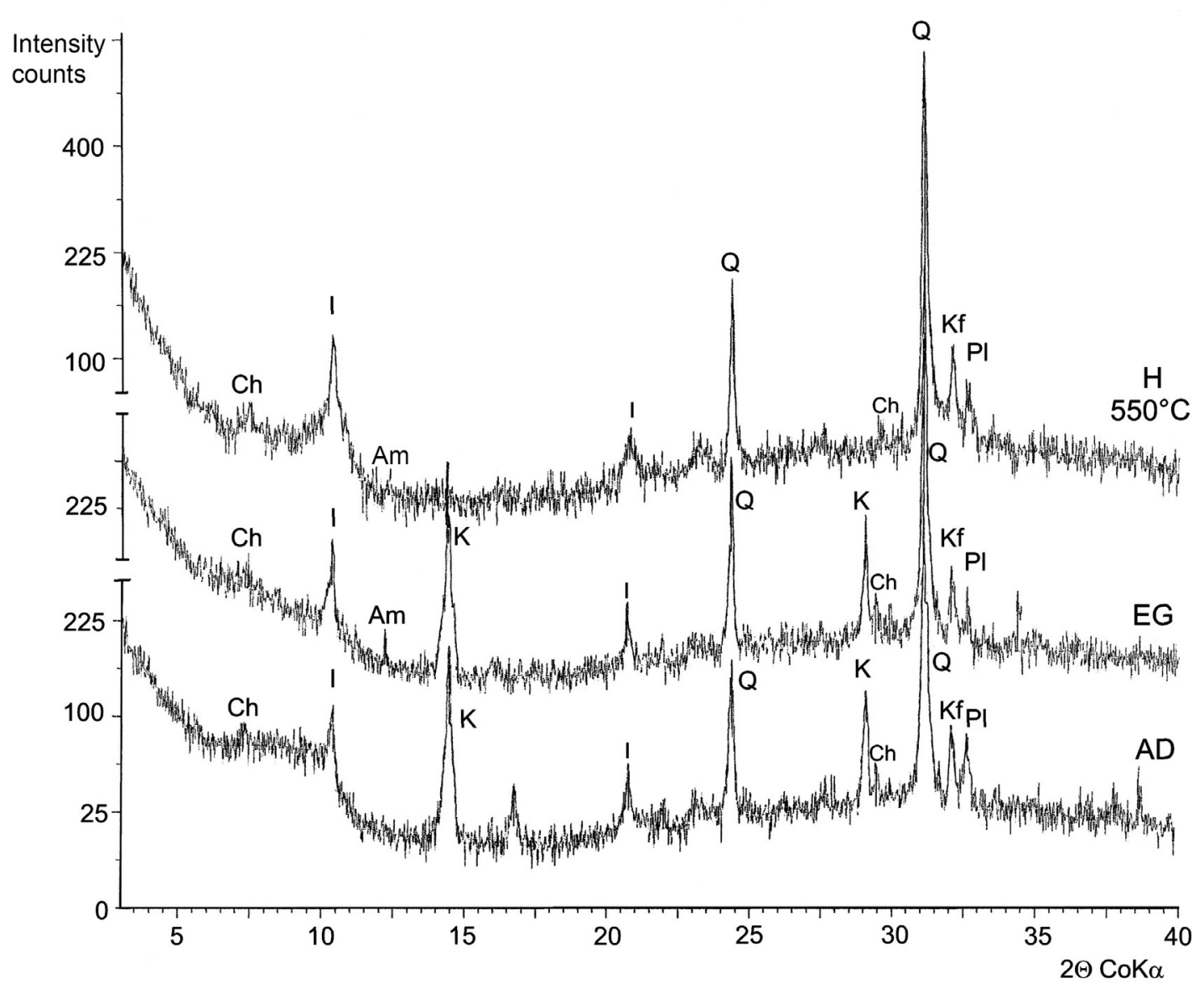

Fig. 11 X-ray diffractogram of clay fraction from the Apk horizon at Brodce, AD - air-dried, EG - ethylene glycol-solvated, $\mathrm{H}$ - after heating, $\mathrm{Ch}$ - chlorite, I - illite, $\mathrm{K}$ - kaolinite, Q - quartz, Kf - K-feldspar, $\mathrm{Pl}$ - plagioclase, Am - amphibole.

amount of 3-5\% in the soil profile. Plagioclase, amphibole and goethite were detected only in some horizons in small amounts. The most common clay mineral is kaolinite, and also elevated are the content of illite (7-8\%). Other clay minerals occur in small amounts. Chlorite is absent from the Bwk horizon and smectite is absent from the Apk horizon.

Clay fraction in the Opukový lom profile on sandy marlstone is dominated by quartz. K-feldspar was identified in the Ok horizon, and gypsum in the bottom part of the soil profile. The amount of kaolinite is relatively high with a tendency to decrease towards the $\mathrm{Ck}$ horizon. Illite occurs in relatively small amounts. Smectite is present in the Ahk and Ck horizons.

Clay fraction in the Zeleneč profile on silty marlstone is characterized by relatively low contents of quartz with the exception of the $\mathrm{Ck}$ horizon which is dominated by quartz. K-feldspar and plagioclase are present in small amounts in some horizons. Kaolinite is present in the amount of 33-41\%. The amount of illite is approximately half the amount of kaolinite. Chlorite and smectite occur as accessory minerals in the Ck horizon.

The distribution of quartz, kaolinite and illite is uneven in the individual soil profiles. Kaolinite and illite predominate over quartz in soils developed on clayey sandstone (Klíčov) and on silty marlstone (Zeleneč) with the exception of the $\mathrm{Ck}$ horizon. These profiles show different kaolinite/illite ratios. The soil profile at Klíčov shows approximately the same amount of kaolinite and illite. The occurrence of chlorite and smectite was also noted here. The ratio of kaolinite: illite $\cong 2: 1$ at the absence of any other clay mineral was found for the soil profile at Zeleneč. The predominance of quartz over kaolinite and illite was recorded in soils developed on calcareous sandstone (Brodce), with the exception of the Bwk horizon, and on sandy marlstone (Opukový lom). Smectite is present in both soil profiles (Brodce and Opukový lom). Of these two sites, chlorite is present only at the Brodce site.

\section{SOIL FORMATION}

Targulian and Krasilnikov (2007) reported that the processes of soil development are limited by the reserves of certain components in parent material. This fact was confirmed by the variability of soil development on different types of silicate-carbonate rocks in the Bohemian Cretaceous Basin. The value of the quartz/calcite ratio in parent material differs among individual rocks. In samples of parent material, it increases in the order: calcareous sandstone (1.06Brodce), silty marlstone (1.51 - Zeleneč), sandy 


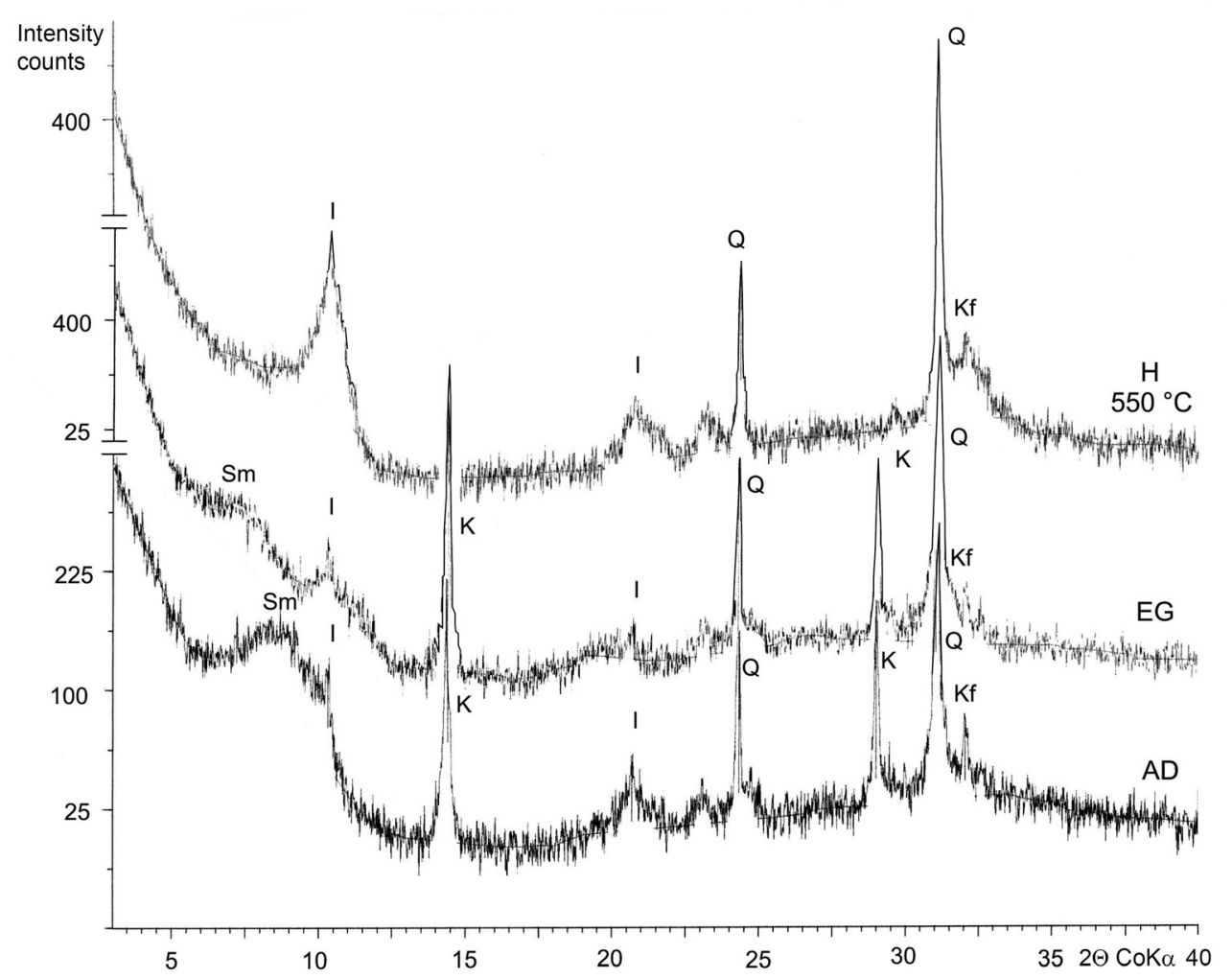

Fig. 12 X-ray diffractogram of clay fraction from the Bwk horizon at Brodce, AD - air-dried, EG - ethylene glycol-solvated, $\mathrm{H}$ - after heating, I - illite, $\mathrm{K}$ - kaolinite, Sm - smectite, Q - quartz, Kf - K-feldspar.

marlstone (2.86 - Opukový lom) and clayey sandstone (3.53 - Klíčov).

Soils developed on clayey sandstone (Klíčov) and sandy marlstone (Opukový lom) are of smaller thickness than soils developed on calcareous sandstone (Brodce) and silty marlstone (Zeleneč).

Soil development at all the studied sites is connected with the process of humification and the presence of the surface Ahk horizon. Qualitative parameters such as organic carbon, total nitrogen and the $\mathrm{C} / \mathrm{N}$ ratio show some differences probably connected with the type of vegetation and land use (for these parameters see Studied sites). The Ahk horizon was also formed below the Ok horizon (Opukový lom) which occurs at the site with forest vegetation. The lowest organic matter content, recorded at the Brodce site, can be associated with the sandy character of the parent material which promotes organic matter decomposition.

The anthropic effect, measured by the organic carbon contents, the presence of the Ok horizon and the thickness of the Ahk and Apk horizons, decreases in the series of Brodce - Zeleneč - Klíčov - Opukový lom, which is clearly connected with the land use. The effect of ploughing on the thickness of the Ahk horizon can be well illustrated by the comparison of sites of Klíčov and Zeleneč, now both used as meadows with trees. The thickness of this horizon at Klíčov, which was never used as arable land, is $18 \mathrm{~cm}$. This contrasts with the Zeleneč site, previously an arable soil, where the Ahk horizon is thicker $(30 \mathrm{~cm})$, with a sharp lower boundary. Its differentiation into two subhorizons is probably connected with this change in land use.

Pedogenetic formation of the subsurface Bwk horizon was comfirmed by a change in color, structure and elevated amount of clay fraction compared to the underlying layers in profiles on calcareous sandstone and silty marlstone. Tomášek and Žáčková (1972) and Ogunwale et.al. (1975) also described the occurrence of subsurface B horizon in soils developed on sandstones but could not provide any details on the character of the $\mathrm{B}$ horizon due to their lack of analytical data.

The intensity of modern pedogenesis in the central part of the Bohemian Cretaceous Basin is higher on calcareous sandstone and silty marlstone. These sites are covered by Cambic Leptosol with the presence of Bwk horizons. The development of the Bwk horizon is possible even under neutral and basic $\mathrm{pH}$ conditions. A partial removal of carbonates and a decrease in the $\mathrm{pH}$ value in the upper part of soil profiles lead to the development of the subsurface Bwk horizon with evidence of weak pedogenetic alteration, which is characteristic for Cambic Leptosols.

The dominant clay minerals of the soil profiles on Cretaceous sediments are kaolinite and illite. The dominance of kaolinite with a smaller amount of illite has been reported from soil profiles on Lower 


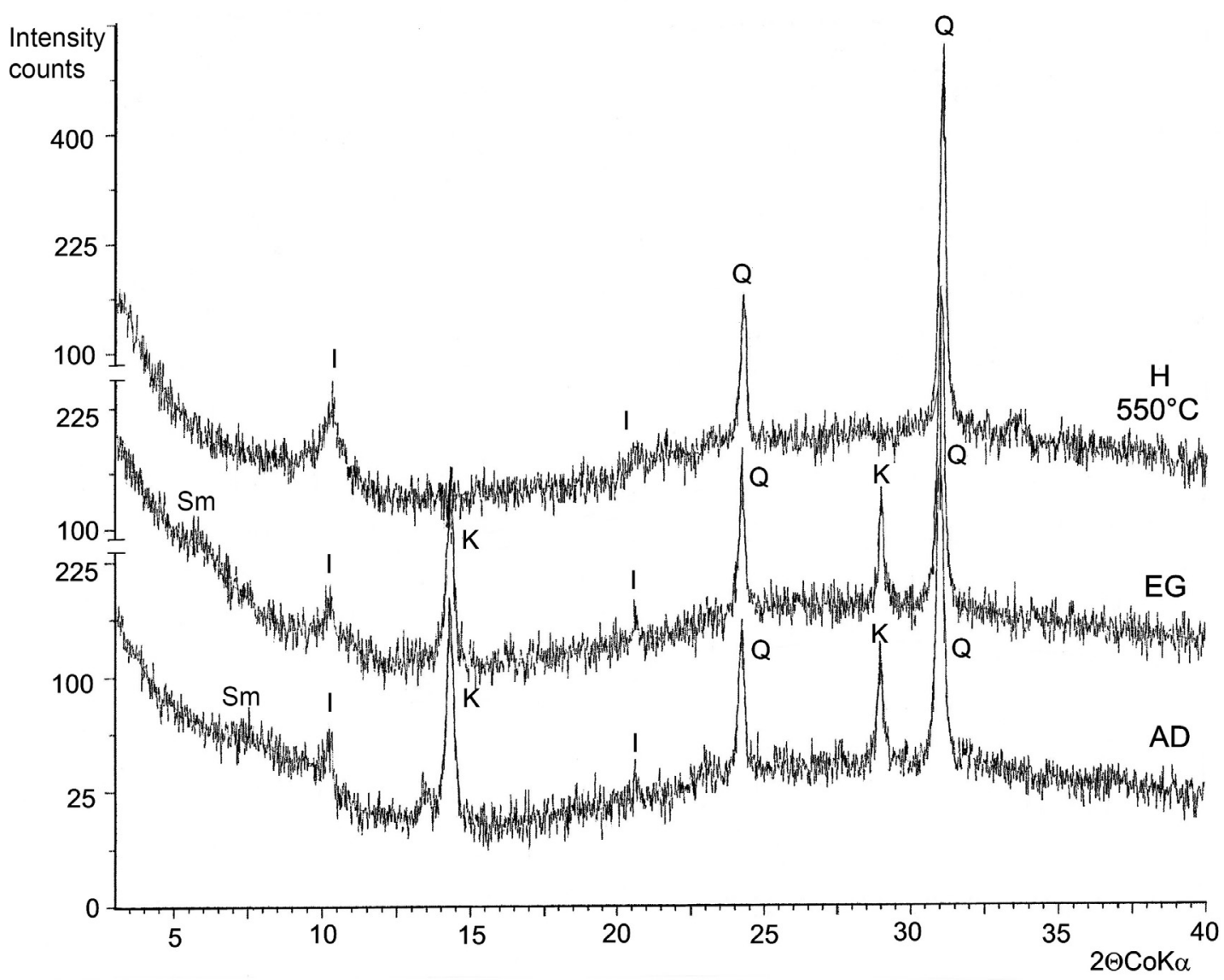

Fig. 13 X-ray diffractogram of clay fraction from the Ahk horizon at Opukový lom, AD - air-dried, EG ethylene glycol-solvated, $\mathrm{H}$ - after heating, I - illite, K - kaolinite, Sm -smectite, Q - quartz.

Cretaceous sandstone in eastern Saudi Arabia by Shadfan and Mashhady (1985). Prevalence of kaolinite over illite in soil profiles of the central Bohemian Cretaceous Basin was found at all sites except for the Klíčov profile. The intensity of pedogenesis is probably connected with the distribution of kaolinite and illite in the soil profiles and with the quartz/calcite ratio in parent material. The occurrence of the Bwk horizon was documented in soils where kaolinite predominates over illite and the quartz/calcite ratio in the rock is relatively low (calcareous sandstone and silty marlstone).

\section{CONCLUSIONS}

The effect of different types of rocks on pedogenesis in the central part of the Bohemian Cretaceous Basin can be reliably assessed as the studied sites show only negligible differences in their climatic conditions and relief characteristics. The parent materials are silicate-carbonate rocks with quartz/calcite ratios of $1.06-3.53$. The dominant minerals of the clay fraction of the studied soils are quartz, kaolinite and illite. Pedogenesis proceeded predominantly in neutral and basic $\mathrm{pH}$ conditions. Calcaric Leptosols are of smaller thickness than Cambic Leptosols. The main pedogenetic process is humifucation. A rapid reduction of the amount of organic matter in profiles is typical for Calcaric Leptosol on clayey sandstone and sandy marlstone. The contents of organic matter decrease gradually down the profile of Cambic Leptosols on calcareous sandstone and silty marlstone.

Higher intensity of pedogenesis was observed in Cambic Leptosols where kaolinite dominated over illite. The occurrence of the Bwk horizon in the studied Leptosols indicates an increasing intensity of pedogenesis and a tendency towards Cambisol development. The Bwk horizon shows a weak pedogenetic alteration, indicated by a change in color, structure and elevated amount of clay fraction compared to the underlying layers. This evidences a partial removal of carbonates. The presence of Bwk horizons was documented on calcareous sandstone (Brodce) and silty marlstone (Zeleneč), which show a more balanced quartz/calcite ratio in parent material: 1.06 for calcareous sandstone and 1.51 for silty marlstone. These results suggest that the most important factor in Leptosol development is the parent material and that their further development towards Cambisols can be hardly expected on silicatecarbonate rocks with a high proportion of quartz. 


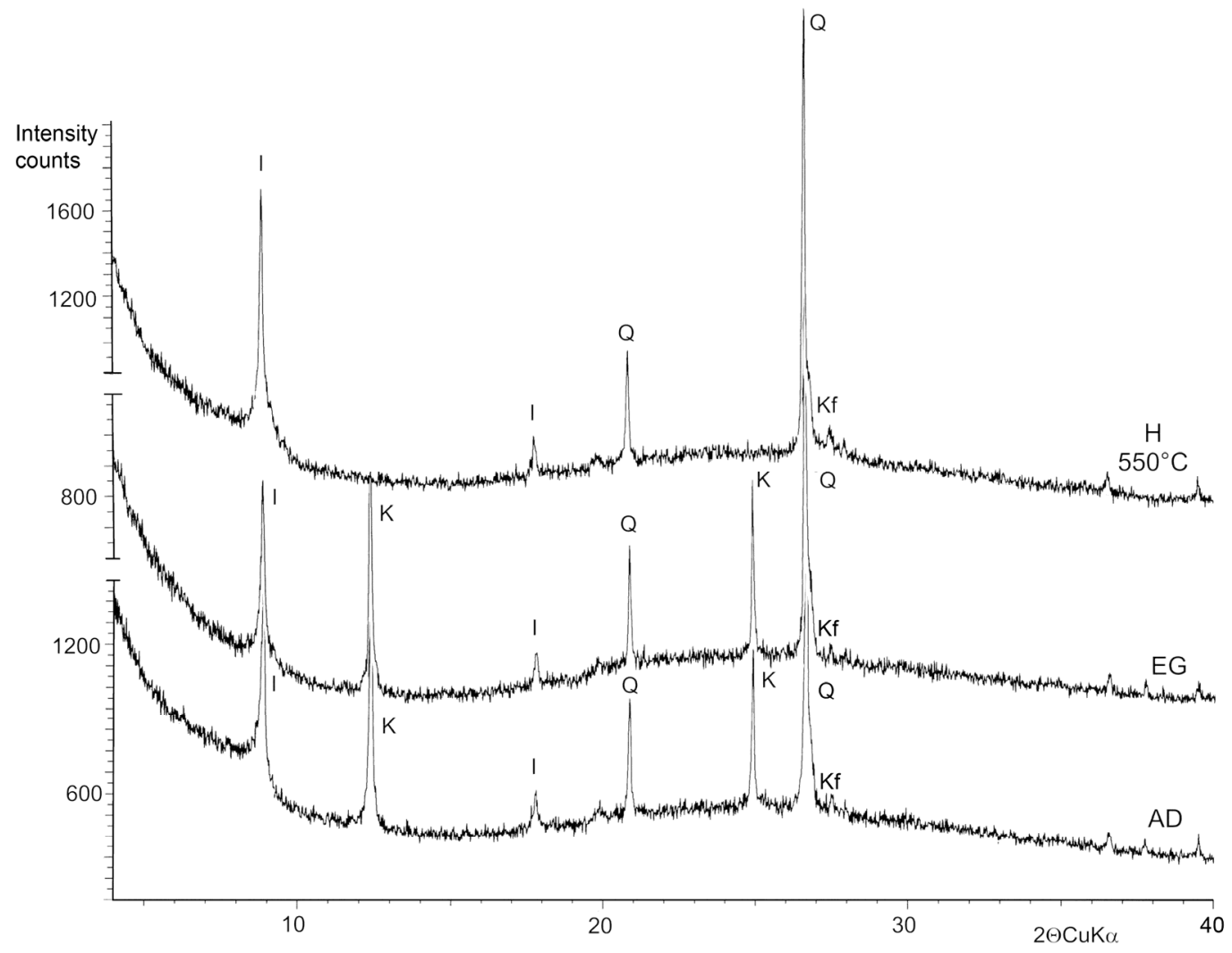

Fig. 14 X-ray diffractogram of clay fraction from the Ahk2 horizon at Zeleneč, AD - air-dried, EG - ethylene glycol-solvated, $\mathrm{H}$ - after heating, I - illite, $\mathrm{K}$ - kaolinite, Q - quartz, Kf - K-feldspar.

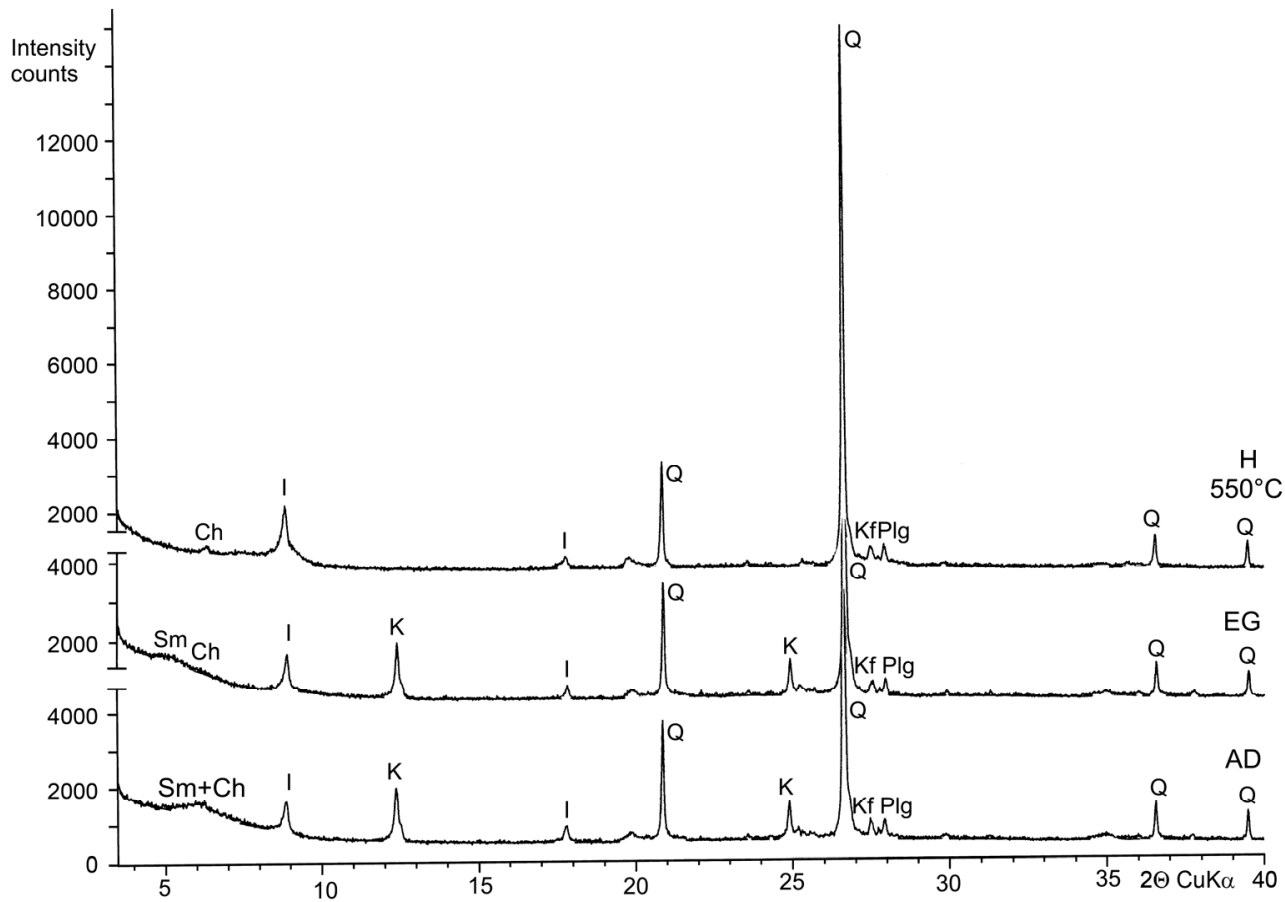

Fig. 15 X-ray diffractogram of clay fraction from the Bwk horizon at Zeleneč, AD - air-dried, EG - ethylene glycol-solvated, $\mathrm{H}$ - after heating, $\mathrm{Ch}$ - chlorite, I - illite, $\mathrm{K}$ - kaolinite, $\mathrm{Sm}$ - smectite, Q - quartz, $\mathrm{Kf}$ - K-feldspar, $\mathrm{Pl}$ - plagioclase. 


\section{ACKNOWLEDGMENTS}

The research is funded by institutional support RVO 67985831 of the Institute of Geology of the Czech Academy of Sciences and the Czech Science Foundation (project GA16-15065S). The authors are especially grateful to Jana Rajlichová for technical support.

\section{REFERENCES}

Baize, D.: 1993, Soil Science Analyses. A Guide to Current Use. John Wiley \& Sons. 192 pp.

Balatka, B. and Kalvoda, J.: 2006, Geomorphological regionalization of the relief of Bohemia. Kartografie, Praha, 80 pp.

Caracciolo, L., Le Pera, E., Muto, F. and Perri, F.: 2011, Sandstone petrology and mudstone geochemistry of the Peruc-Korycany Formation (Bohemian Cretaceous Basin, Czech Republic). International Geology Review, 53, No. 1, 1003-1031. DOI 10.1080/00206810903429011

Čech, S., Klein, V., Kř́žž, J. and Valečka, J.: 1980, Revision of the Upper Cretaceous stratigraphy of the Bohemian Cretaceous Basin. Věstník Ústředního ústavu geologického, 55, No. 5, 277-296.

Daniels, R.B. and Gamble, E.E.: 1978, Relations between stratigraphy, geomorphology and soils in Coastal Plain areas of Southeastern U.S.A. Geoderma, 21, No. 1, 41-65. DOI 10.1016/0016-7061(78)90004-6

do Nascimento, D.L., Batezelli, A., and Ladeira, F.S.B.: 2019, The paleoecological and paleoenvironmental importance of root traces: Plant distribution and topographic significance of root patterns in Upper Cretaceous paleosols, Catena. 172, 789-806.

DOI: $10.1016 /$ j.catena.2018.09.040

Hradecká, L.: 1994, Cretaceous sediments on the map sheet Benátky nad Jizerou. Zprávy o geologických výzkumech v roce 1993, 37-38, (in Czech).

IUSS Working Group WRB: 2015, World Reference Base for Soil Resources 2014, update 2015 International soil classification system for naming soils and creating legends for soil maps. World Soil Resources Reports 106. FAO, Rome, $192 \mathrm{pp}$.

Jackson, M.L.: 1979, Soil chemical analyses - advanced course. Madison, Wisconsin, $895 \mathrm{pp}$.

Jahn, R., Blume, H.P., Asio, V.B., Spaargaren, O. and Schad, P.: 2006, Guidelines for soil description. Fourth edition. FAO, Rome, 97 pp.

Joint Committee on Powder Diffraction Standards: 1986, Mineral Powder Diffraction File: Data Book, Swarthmore, Pennsylvania. 1186 pp.

Kovanda, J., ed.:1995, Synoptic geological map of Prague and its environs. Czech Geological Survey, Prague.

Loveland, P.J. and Findlay, D.C.: 1982, Composition and development of some soils on glauconitic Cretaceous (Upper Greensand) rocks in southern England. Journal of Soil Science, 33, No. 2, 279-294.

DOI 10.1111/j.1365-2389.1982.tb01766.x

Mack, G.H.: 1992, Paleosols as an indicator of climatic change at the early-late Cretaceous boundary southwestern New Mexico. Journal of Sedimentary Research, 62, No. 3, 483-494.

DOI: 10.1306/D426792E-2B26-11D7-8648000102C1865D
McCarthy, P.J. and Plint, A.G.: 2003, Spatial variability of paleosols across Cretaceous Interfluves in the Dunvegan Formation, NE British Columbia, Canada: palaeohydrological, palaeogeomorphological and stratigraphic implications. Sedimentology, 50, No. 6, 1187-1220. DOI 10.1046/j.1365-3091.2003.00600.x

Munsell Soil Color Charts: 2000, Revised Washable Edition. Munsell Color, GretagMacbeth, New Winsdor, $10 \mathrm{pp}$.

Ogunwale, J.A., Ashaye, T.I., Odu, C.T.I. and Fayemi, A.A.A.: 1975, Characterization of sandstone-derived soils in ecological zones of Nigeria. Geoderma, 13, No. 4, 331-347. DOI 10.1016/0016-7061(75)90046-4

Pansu, M. and Gautheyrou, J.: 2006, Handbook of Soil Analysis: Mineralogical, Organic and Inorganic Methods. Springer, Berlin-Heidelberg. 993 pp.

Quitt, E.: 1971, Climatic regions of Czechoslovakia. Studia Geographica, 16, Československá akademie věd, Geografický ústav, Brno, 82 pp., (in Czech).

Shadfan, H. and Mashhady, A.S.: 1985, Distribution of palygorskite in sediments and soils of eastern Saudi Arabia. Soil Science Society of America Journal, 49, No. 1, 234-250. DOI 10.2136/sssaj1985.03615995004900010050x

Soil Survey Staff: 2014, Keys to Soil Taxonomy, 12th edition. USDA-Natural Resources Conservation Service, Washington DC, $360 \mathrm{pp}$.

Targulian, V.O. and Krasilnikov, P.V.: 2007, Soil system and pedogenic processes: Self-organization, time scales, and environmental significance. Catena, 71, No. 3, 373-381. DOI 10.1016/j.catena.2007.03.007

Taylor, T.G.: 1996, Pedogenic clay-mineral transformation in the Weald Basin: Implications for Early Cretaceous hinterland climate reconstructions. Cretaceous Research, 17, No. 1, 103-108. DOI 10.1006/cres.1996.0008

Tomášek, M. and Žáčková, M.: 1972, Topographical series of soils on weathered calcareous sandstones of the Bezděz Plateau. Rostlinná výroba, 18 (XLV), No. 2, 115-120, (in Czech).

van Reeuwijk, L.P.: 2002, Procedures for soil analysis. Technical paper, 9. International Soil Reference and Information Centre. Wageningen. $97 \mathrm{pp}$.

Varela, A.N., Raigembom, M.S., Richiano, S., White, T., Poire, D.G. and Lizzoli, S.: 2018, Late Cretaceous paleosols as paleoclimate proxies of high-latitude Southern Hemisphere: Mata Amarilla Formation, Patagonia, Argentina. Sedimentary Geology, 363, 8395. DOI: $10.1016 /$ j.sedgeo.2017.11.001

Zelenka, P.: 1987, Lithofacies development of Cretaceous deposits in Prague and its surroundings. Sborník geologických věd - Geologie, 42, 89-112, (in Czech).

Ziegler, V.: 1994, The sediments of the Bohemian Cretaceous Basin in Prague. Natura Pragensis. Studie o prírodě Prahy, 11. Český ústav ochrany prírody. Středisko pro hlavní město Prahu, Praha. 37 pp., (in Czech).

Žigová, A. and Št’astný, M.: 2014: Pedogenesis on volcanic rocks in protected landscape areas in Central and North Bohemia. Soil and Water Research, 9, No. 4, 153-160. DOI: 10.17221/23/2014-SWR 